\title{
A MEDIAÇÃO PEDAGÓGICA EM UMA DISCIPLINA \\ CIENTÍFICA COMO REFERÊNCIA FORMATIVA \\ PARA A DOCÊNCIA DE FUTUROS PROFESSORES \\ DE BIOLOGIA
}

\section{The pedagogical mediation in a scientific course as a formative reference for future teachers' practice in biology}

\author{
Lenice Heloísa de Arruda Silva ${ }^{1}$ \\ Roseli Pacheco Schnetzler ${ }^{2}$
}

\begin{abstract}
Resumo: 0 trabalho enfoca a mediação pedagógica de um professor universitário no contexto de uma disciplina científica (Fisiologia) oferecida a licenciandos em Biologia. Investiga como tal mediação pode se tornar uma referência formativa para os futuros professores, particularmente por meio do processo de elaboração conceitual que o formador promove em suas aulas. Para tal, foram observadas, registradas e transcritas aulas teóricas e práticas do formador, gravadas em áudio, bem como realizadas entrevistas semi-estruturadas com alguns de seus alunos. Os dados são construídos e interpretados segundo procedimentos teórico-metodológicos pautados em uma perspectiva histórico-cultural do desenvolvimento humano, adotando-se a análise microgenética para investigar o processo de ensino e a análise do conteúdo para os depoimentos dos alunos. Os resultados revelam que a mediação pedagógica do formador promove elaboração conceitual em seus alunos, que a consideram um exemplo a ser adotado em suas futuras atuações docentes, evidenciando o importante papel que professores universitários de disciplinas científicas específicas podem ter na formação docente inicial.
\end{abstract}

Palavras-chave: Mediação pedagógica. Formação docente em Biologia. Professor universitário.

Abstract: This research focuses how a lecturer's pedagogical mediation in a biological course may contribute to a future teachers' practice in Biology, particularly related to the conceptual elaboration process. The theoretical and methodological approach of the investigation is based on a historical and social framework. Data collection comprises observation and audio tape recording of the lecturer's lessons and interviews with students, which are analyzed according with microgenetic and conceptual approaches. Results reveal the importance that lecturer's pedagogical mediation may have for the initial teacher education in Biology.

Keywords: Pedagogical mediation. Biological teacher education. Lecturer's teaching practice.

\footnotetext{
${ }^{1}$ D ocente, Universidade Federal do Mato G rosso do Sul (UFMS), Programa de Pós-G raduação em Educação. <leniceheloisa@ig.com.br>

${ }^{2}$ D ocente, Universidade Metodista de Piracicaba (Unimep), Programa de Pós-G raduação em Educação.

$<$ rpschnet@unimep.br>
} 


\section{Introdução}

Este trabalho aborda a formação de futuros professores de Biologia, enfocando uma problemática central: a insuficiência de preparação dos licenciandos no domínio dos conteúdos a ensinar. Tal domínio envolve não somente o conhecimento dos conteúdos da disciplina que estarão sob suas responsabilidades, mas, também, conhecimentos relativos a como elaborá-los pedagogicamente, tornando-os disponíveis para serem apropriados e (re)elaborados pelos seus futuros alunos (CARVALHO e G IL-PÉREZ, 2001; MARCELO, 1999).

0 conhecimento pedagógico é de grande complexidade, sendo o que diferencia 0 professor dos especialistas das diversas áreas do saber. Assim, tal conhecimento vai além daquele da disciplina em si, situando-se na dimensão da disciplina a ensinar, pois nele estão incluídos os modos que o professor utiliza para representar e formular os conhecimentos científicos de sua disciplina, elaborando-os em conhecimentos compreensíveis para os alunos. Ele inclui, também, uma compreensão do que faz a aprendizagem fácil ou difícil. Isso implica que o professor conheça as preconcepções que os alunos, de diferentes idades e experiências, trazem consigo sobre determinados conceitos freqüentemente ensinados. Considerando que tais preconcepções são, geralmente, distantes do conhecimento científico, o professor precisa conhecer um maior número de estratégias apropriadas para que seu ensino propicie a reorganização e compreensão dos alunos sobre os conceitos abordados. Nesse sentido, tal conhecimento possibilita ao docente articular diferentes conhecimentos, permitindo-lhe a elaboração de seus conteúdos de ensino, os quais constituem o aspecto central de vida da sala de aula e da educação escolar sendo, portanto, fundamental nas programações e na organização de atividades de ensino-aprendizagem (SHULMAN, 1986).

Nesses termos, a razão da referida problemática se prende ao fato de que, nas disciplinas científicas específicas dos cursos de licenciatura em Biologia, Física, Q uímica, pouca ou nenhuma consideração tem sido dada para elaborações pedagógicas facilitadoras de aprendizagem. Isto porque, usualmente, os professores/ formadores vêm interpretando e mantendo um processo de ensino-aprendizagem em termos de transmissão-recepção, que atribui grande peso à quantidade de conteúdos científicos, e não à sua elaboração na sala de aula por parte dos alunos. Nesse modelo, cabe ao professor transmitir os conteúdos previamente elaborados aos alunos, que assumem um papel de meros receptores (CICILLINI, 1997; MARCELO, 1999; MALDANER, 2000; SCHNETZLER, 2000). Por isso, muitas das críticas aos cursos de licenciatura apontam para a pouca eficácia dos mesmos em termos de formação docente.

Assumindo que é por intermédio das práticas pedagógicas dos professores/ formadores de disciplinas científicas específicas que os futuros professores podem se apropriar dos conceitos científicos e elaborá-los, e que tais práticas revelam modos de como os ensinar, é que justificamos a investigação da questão abaixo, visando contribuir para um melhor entendimento da problemática aqui enfocada.

\section{A questão de investigação e sua fundamentação teónico-metodológica}

Com base em uma perspectiva histórico-cultural do desenvolvimento humano, que concebe o processo de elaboração de conhecimentos como prática social, envolvendo uma 
relação entre sujeito e objeto de conhecimento mediada por outro sujeito, investigamos: como a mediação pedagógica de um professor universitánio, ao ensinar conceitos científicos, pode se constituir como referência formativa para futuros professores de Biologia?

Esta investigação se fundamenta em idéias de Vygotsky e Bakhtin, que, ao considerarem que a ação do sujeito sobre o objeto de conhecimento é mediada socialmente pelo outro e pelos signos, têm oferecido subsídios para a análise de relações entre contexto de escolarização, atividade cognitiva e desenvolvimento do sujeito. Nessa perspectiva, o processo de elaboração de conhecimentos é concebido como processo psicológico que emerge dos modos de vida dos indivíduos em interação, assumindo que é por meio da linguagem que as funções psicológicas vão se constituindo. Assim, o conhecimento tem sua gênese na dinâmica interativa das relações sociais, as quais são constitutivas do indivíduo humano como sujeito (SMO LKA, 1997; GÓES, 1997).

D esse ponto de vista, no contexto escolar, o aluno é um sujeito interativo, que "elabora conhecimentos sobre os objetos em processos necessariamente mediados pelo outro e constituídos pela linguagem" (GÓES, 1997, p. 13). O papel mediador do outro, professor/ formador, se destaca não somente nos processos de apropriação e elaboração de conhecimentos pelo indivíduo, aluno/ licenciando, mas, também, na sua constituição como sujeito (futuro professor). Já a linguagem, especialmente a palavra como signo, é principal agente de abstração e generalização, assumindo um papel central como mediadora na formação da consciência e na organização das ações, assim como na compreensão e na interpretação de conceitos/ conhecimentos por parte dos sujeitos (VYGOTSKY, 2000b; BAKHTIN, 1997).

Essa concepção da linguagem, na abordagem dos aspectos institucionais, tem uma dimensão constitutiva, pois à palavra é atribuído "o material semiótico privilegiado do psiquismo humano" (BAKHTIN, 1997, p. 38). Nessa perspectiva, conforme Machado (1999, p. 56), há um entendimento de que "é no discurso e pelo discurso que os conhecimentos são elaborados". Explicitando essa idéia, Smolka (2003, p. 40), expressa que: "é no sentido da internalização do discurso de outrem que Bakhtin nos fala (...) do movimento de apreensão das "palavras alheias" e na transformação dessas "palavras alheias" em palavras próprias". D esse modo, a elaboração de conhecimentos "emerge como processo de articulação, pelo confronto, de muitas vozes sócio-historicamente definidas, em condições de interação - compreensão/ expressão - determinadas. Configura-se como um processo discursivo" (FONTANA, 1996, p. 280). Esses aspectos são essenciais para a análise do processo de elaboração/ compreensão de conceitos na sala de aula, em especial, da universidade, já que nesta a palavra é o principal modo de ação pedagógica e de elaboração de conhecimentos. Conforme Machado (1999), nas interações de uma sala de aula, as vozes do livro didático, dos textos científicos, do professor, das experiências e do conhecimento cotidiano encontram-se e confrontam-se, fazendo parte desse processo.

Com base nessas idéias, adota-se a abordagem da análise microgenética que prioriza a análise de processos, explorando-se uma microhistória do processo de ensino do professor/ formador, privilegiando suas interações verbais na relação com seus alunos. A análise microgenética pode ser caracterizada como uma forma de conhecer que é orientada para minúcias e ocorrências residuais, como indícios, pistas, signos de aspectos relevantes de um processo em curso; que elege episódios típicos e atípicos, os quais permitem interpretar o fenômeno de interesse; que é centrada na intersubjetividade e no funcionamento enunciativo-discursivo dos 
sujeitos; e que se guia por uma visão indicial e interpretativo-conjetural. Em síntese, uma "perspectiva de investigação da constituição de sujeito no âmbito dos processos intersubjetivos e das práticas sociais" (G Ó ES, 2000, p. 21).

Vygotsky (1993, p. 213) argumenta que o processo de desenvolvimento dos conceitos sistematizados/ científicos se produz nas condições reais do processo de ensino, que constitui uma forma de interação sistemática e deliberada do professor com 0 aluno. Nesta interação, desenvolvem-se as funções psicológicas superiores do aluno com a ajuda e participação do professor. Esse desenvolvimento encontra sua expressão na crescente utilização dos conceitos, independentemente do contexto no qual foram produzidos e, também, no fato de que o pensamento científico do aluno avança até alcançar um determinado nível de desenvolvimento em relação à tomada de consciência e ao uso deliberado dos mesmos. "O fundamento da tomada de consciência está na generalização dos próprios processos psíquicos, o que conduz ao seu domínio". Neste sentido, a apropriação de conceitos científicos por parte do indivíduo pode levá-lo a se conscientizar dos próprios processos mentais.

A elaboração conceitual requer o desenvolvimento de uma série de funções psicológicas superiores, tais como: a atenção voluntária, a memória lógica, a abstração, a comparação, a dedução, a síntese. Tais funções são altamente complexas e, por isso, os conceitos não podem ser simplesmente memorizados e assimilados tanto em termos psicológicos quanto práticos. Mesmo reconhecendo que o processo de elaboração de conceitos seja um processo único e integrado, Vygotsky $(1993,2000 \mathrm{~b})$ destaca a necessidade de se diferenciar o desenvolvimento dos conceitos cotidianos do desenvolvimento de conceitos científicos, considerando as diferentes condições sociais internas e externas de elaboração em cada uma dessas situações. Enquanto os primeiros são elaborados por meio da experiência diária, isto é, nas interações com pessoas do meio social imediato, ocorrendo de maneira assistemática e não-deliberada, os conceitos científicos são elaborados por meio da aprendizagem sistematizada na escola.

Apesar das diferenças entre os conceitos cotidianos e os conceitos científicos, segundo Vygotsky (2000c, p. 136), eles se relacionam e se influenciam constantemente, pois constituem parte de um único processo - o desenvolvimento da formação de conceitos - , que não significa um conflito entre formas antagônicas e mutuamente exclusivas, mas sim, um processo que é essencialmente unitário. Assim, considerando que o indivíduo elabora conhecimentos antes mesmo de freqüentar a escola, os conceitos cotidianos, já dominados pelo aluno, e os conceitos científicos articulam-se dialeticamente em sua mente e, nesta articulação, tanto um quanto outro se transformam reciprocamente. 0 s conceitos cotidianos propiciam o confronto dos conceitos científicos/ escolares com uma situação concreta, criando "uma série de estruturas necessárias para a evolução dos aspectos mais primitivos e elementares de um conceito". Já os conceitos científicos criam estruturas para o desenvolvimento dos conceitos cotidianos em relação à sistematização, à consciência e ao uso deliberado, que são características de um tipo de percepção generalizante própria da atividade intelectual.

A partir disso, Vygotsky (1993) infere que esse nível de desenvolvimento é produto/ produção das condições do processo de ensino, cujo aspecto fundamental é a singular interação entre professor e aluno, junto com os conhecimentos que são transmitidos a este segundo um determinado sistema. Assim, destaca a importância da colaboração do professor, considerando que, no processo de elaboração interpessoal, o aluno faz tentativas de imitar a análise 
intelectual, ainda que não a tenha apreendido completamente. Ao utilizar-se de tal análise, mesmo que pela via da imitação, o aluno inicia sua elaboração, transformando e desenvolvendo sua atividade cognitiva (FO NTANA, 1996).

Nesses termos, no contexto escolar, as interações entre os sujeitos têm uma orientação explícita e deliberada, no sentido de aquisição de conceitos sistematizados/ científicos pelo aluno. Nessas interações, o aluno é colocado diante de uma tarefa particular: "entender as bases dos estudos científicos, ou seja, um sistema de concepções científicas" (VYG OTSKY, 2000a, p. 174). O s conceitos científicos fazem parte de sistemas explicativos globais, organizados dentro de uma lógica socialmente construída e reconhecida como legítima, que tem por finalidade garantir-lhes coerência interna. Também, nesse contexto, as atividades envolvendo a apreensão dos conceitos sistematizados/ científicos são organizadas de maneira discursiva e lógico-verbal e, assim, a relação do aluno com o conceito é sempre mediada por algum outro conceito. Além disso, as interações entre os sujeitos, isto é, entre professor e alunos, se caracteriza como uma relação de ensino, cuja finalidade imediata - ensinar/ aprender ou formar/ ser formado - é explicita para ambos, os quais ocupam lugares sociais diferenciados e hierarquicamente organizados (FONTANA, 1996).

Nessa relação de ensino, o papel do professor/ formador é o de mediar aos alunos, de forma explícita e deliberada, conhecimentos sistematizados/ científicos, os quais, no caso da universidade, dizem respeito tanto aos conhecimentos da área específica quanto aos da cultura profissional. Nessa mediação pedagógica, ele compartilha com os alunos sistemas conceituais instituídos, linguagens, instrumentos, estratégias, procedimentos, atitudes, valores e saberes próprios dessa cultura. Isso tudo envolve os conceitos já dominados pelos alunos, bem como as ações e concepções dos professores/ formadores, imbricados nas condições sociais reais de produção daqueles conhecimentos dentro do contexto institucional de escolarização ou de formação profissional. Com base nessas idéias, destacamos a importância de investigarmos como a mediação pedagógica de um professor/ formador de disciplina científica da área biológica pode promover a elaboração de conceitos científicos pelos licenciandos, constituindose como referência formativa para suas futuras ações docentes.

\section{Procedimentos metodológicos}

O desenvolvimento deste trabalho implicou a investigação da prática pedagógica de um formador de disciplina específica, integrante de um corpo docente de 17 professores universitários, responsáveis pelo oferecimento de trinta disciplinas de conteúdos específicos de Biologia, de um curso noturno de licenciatura em Ciências Biológicas, pertencente a uma universidade confessional localizada em um município do Estado de São Paulo.

0 interesse na investigação da prática pedagógica daquele formador foi resultado da análise de um questionário aplicado a 78 licenciandos dos dois últimos semestres do referido curso, contendo duas questões abertas, para que indicassem qual/ quais formador(es) das disciplinas de conteúdos específicos de Biologia mais contribuiu/contribuíram e/ ou tem/ têm contribuído para suas futuras ações docentes e o porquê de tais escolhas. A escolha desse formador se justifica por ter sido indicado pela grande maioria dos licenciandos (71\%). Além disso, a diferença percentual de sua indicação para o segundo escolhido (37\%), reiterou 0 
nosso interesse de investigar sua prática pedagógica, com o propósito de evidenciar como ele promove a elaboração de conceitos científicos em sua disciplina. Esse formador exerce 0 magistério superior há 12 anos. Sua formação básica é em Biologia (licenciatura plena), sendo mestre e doutor na área de Fisiologia.

Para a construção dos dados da investigação, foram observadas e registradas em áudio cinco de suas aulas teóricas e práticas, com duração de duas horas cada uma. Nas transcrições dessas aulas e por meio da análise microgenética, foram recortados episódios que evidenciam aspectos relativos a como o formador abordou a elaboração de conceitos. Essas aulas foram referentes à disciplina de Fisiologia, ministrada para uma classe de 65 alunos do $5^{\circ}$ semestre, dos quais dez foram escolhidos de forma aleatória para serem entrevistados. Nessas entrevistas, de tipo semi-estruturada, procuramos obter informações sobre a prática pedagógica do professor, privilegiando questões relativas ao desenvolvimento dos conteúdos, às estratégias de ensino por ele utilizadas e à aprendizagem. Tais entrevistas foram transcritas e analisadas, no intuito de buscar indícios para apreender como os alunos elaboraram relações entre os conceitos científicos e os modos de ensinar do referido professor formador.

\section{Resultados}

\section{A prática pedagógica do formador: aspectos gerais}

No início de cada aula, o formador escrevia na lousa o tema central a ser tratado. Entregava a cada aluno um texto auxiliar, geralmente sobre resultados de pesquisas referentes ao tema e/ ou um resumo da aula. D irigia-se aos alunos explicitando o que seria abordado na aula, como iria desenvolvê-la e quais eram os seus objetivos. Para a explanação dos temas e dos conceitos a eles relacionados, o professor utilizava a exposição oral, com uso de esquemas e desenhos na lousa e de transparências para reforçar/ embasar suas explicações. No desenvolvimento dos temas, o professor procurava articular os conceitos centrais de cada tema com outros conceitos e com situações relacionadas ao cotidiano dos alunos. No final das aulas, 0 professor retomava de forma sintética os conceitos nelas abordados.

\section{Um exemplo: a elaboração conceitual na aula sobre estresse}

\section{Descrição da aula}

No que diz respeito à elaboração conceitual, o professor tematizou o conceito de Estresse definindo-o como "uma reação do organismo a uma condição indutora interna ou ex terna que promove uma resposta orgânica ou comportamental", enfatizando a relação do tema central com um conceito central da Fisiologia (homestasia), que poderia ser assim representada: estresse (alteração do comportamento) - (causado por um) agente agressor - (alteração que se manifesta via) produção hormonal - (promove) adaptação - (mantém) homeostasia. 0 formador desenvolveu esses conceitos dando destaque ao seguinte conjunto de idéias: como se 
dá a produção hormonal; resposta hormonal no estresse; estresse e estado de estresse (manifestações orgânicas); adaptação (homeostasia).

Explicou que a aula consistia, primeiro, de uma discussão teórica e, posteriormente, em demonstrar por meio de procedimentos práticos, de laboratório, a variação de substâncias químicas no corpo do animal (rato), decorrente de reações metabólicas durante a sua exposição a determinadas condições ambientais, como a contenção e o frio. Explicou, também, que um dos objetivos dessa aula seria o de gerar um estresse em um animal (rato), para que eles pudessem entender e avaliar uma situação de estresse, assim como seus mecanismos adaptativos. A essas explicações o formador acrescentou: "Para que serve isso? Para a gente entender estresse, ver as oisas sobre 0 estresse, mecanismos adaptativos, e para quem da biologia for para a área de pesquisa é uma técnica de rotina para vooê determinar se há um estresse no bicho.... V ooê vai ex plicar o estresse!"

Então, começou a desenvolver o tema central pela concepção cotidiana de estresse: "Primeira coisa que nós vamos entender, o indivíduo está acostumado a dizer assim: nossa!! E stou estressado!! N ossa, eu não agüento mais!" Articulou essa concepção com o conceito científico, definindo estresse como: "0 estresse vai ser a sua resposta, a resposta do seu organismo frente a uma condicão indutora. 0 u seja, vai ex istir uma condição, quer seja física, quer seja psíquica, ou mista, quea grande maioria aqui tem. E ssas reações vão culminar com uma resposta do seu organismo, uma resposta orgânica ou comportamental. E stresse, para nós, vai ser uma reação do organismo!! É o organismo que reage a uma condição indutora ex terna ou interna".

Para a compreensão desse conceito, o formador acrescentou o conceito de agente agressor, definindo-o como "todos os estímulos que promovem 0 aparecimento da resposta orgânica ou comportamental". Por meio de uma situação do cotidiano, transcrita a seguir, ele estabeleceu uma relação entre os conceitos de estresse e de agente agressor, e exemplificou reações de estresse induzidas por estímulos externos. "E x emplo, a $\mathrm{H}$ ellen mudou de casa, ela morava aqui e mudou lá pra serra. Só de ela mudar de ambiente já significa que o seu organismo vai ter de se adaptar a essa nova resposta. 0 utra cisa, você foi namorar esse fim de semana e ela virou e falou: vamos marcar a data? E agora? E stressou! V ocê chegou em casa e a sogra falou: vou passar sete dias aquil"

Em seguida, ele trouxe um outro conceito associado ao estresse, o de adaptação, dizendo "que o principal objetivo do estresse é adaptar 0 indivíduo frente à nova condição gerada pelo agente agressor". Então, explicou que a resposta do organismo ao estresse vai ser hormonal. Por meio de uma outra situação do cotidiano, ele estabeleceu relações entre os conceitos de agente agressor e adaptação. "V amos pegar um ex emplo popular, imagine um motorista de ônibus. E le liga 0 ônibus. $\mathrm{N}$ a hora que ele comecou a andar, alguém dá um sinal, ele pára! Comecou a andar de novo, um cara pux a a campainha, ele pára de novo! Imagine que ele faz isso oito horas por dia. E le vai parando, vai parando, vai parando. Se ele não se adaptasse, isso seria uma condição altamente estressora. A gente só sobrevive porque a gente consegue se adaptar às condiọ̃es".

Essas relações, por sua vez, foram articuladas com o conceito de resposta hormonal. 0 formador explicou que essa resposta orgânica envolve a participação de algumas áreas cerebrais de controle. Para que os alunos visualizassem essas regiões, ele utilizou uma transparência que continha um esquema da estrutura do sistema nervoso e dos centros de controle do organismo. D estacou que o principal órgão envolvido na resposta hormonal é o hipotálamo, e assim trouxe o conceito de homeostasia, definindo-o como "o grande equilíbrio do organismo. A maneira cmo 0 organismo está equilibrado". Articulou esse conceito e o papel do hipotálamo, explicando que este participa constantemente no equilíbrio do organismo, controlando oxigena- 
ção, tensão na parede dos vasos, secreção hormonal, entre outros. Acrescentou que "0 hipotálamo é 0 grande centro integralizador ao qual chega uma série de informa ọoes sensoriais, evalendo-se delas começa a programar, analisar e projetar uma resposta periférica, desencadeando, no organismo, a resposta frente ao agente agressor".

O formador prosseguiu explicando que, além do hipotálamo, entre os órgãos envolvidos no estresse, estão também a hipófise e a glândula supra-renal. Para que os alunos visualizassem a localização dessa glândula no organismo, bem como a sua função no estresse, 0 formador utilizou uma transparência que continha uma foto com a localização da glândula, suas divisões e locais de produção dos hormônios. Assim, ele explicou aspectos da anatomia e fisiologia, bem como o controle da produção e liberação de seus hormônios. A seguir, apresentou uma síntese da resposta hormonal no estresse. Após essa síntese, o formador falou que os hormônios produzidos e liberados na corrente sangüínea durante 0 estresse causam reações em outros órgãos. Ao trazer essa explicação, acrescentou ao conceito de estresse um outro conceito, o de estado de estresse, dizendo que, neste, inicialmente, o hipotálamo ativa o sistema nervoso simpático, que induz a liberação do hormônio noradrenalina em alguns órgãos específicos. No coração, esse hormônio atua aumentando a freqüência cardíaca, a força de contração, a pressão arterial e o fluxo sanguíneo nos músculos. No fígado, provoca a glicogenólise (quebra do glicogênio), aumento da glicemia circulante; glicólise, aumento do metabolismo da glicose e aumento do metabolismo tecidual.

A síntese do formador enfatizou que, no estado de estresse, o indivíduo precisa aumentar o trabalho celular para que possa reagir frente à situação. Reforçou que, naquele estado, o hipotálamo aciona a hipófise que, por sua vez, libera o hormônio adrenocorticotrófico. Este vai em direção à glândula supra-renal, aumentando a secreção do hormônio cortisol, o qual reduz a reação inflamatória, a resposta imune, e aumenta a expectativa para respostas à cicatrização. Nessa síntese, o formador explicou também que, no estado de estresse, há um aumento do metabolismo tecidual, do tônus muscular, da capacidade de viǵlia e redução do sono, para que 0 indivíduo possa reagir melhor. Concluiu dizendo que o hipotálamo aciona o sistema nervoso simpático que, por sua vez, aciona as glândulas supra-renais, que liberam adrenalina e noradrenalina, as quais influenciam em todo processo cardiovascular, respiratório e digestivo, fazendo com que o indivíduo se adapte às novas condições geradas pelo estresse.

D epois dessa explanação, o formador começou a desenvolver a atividade prática. Nesse momento, os alunos se reuniram em volta da bancada na qual o professor desenvolveria 0 experimento. Essa parte da aula foi iniciada com uma explicação sobre por que iria utilizar 0 rato para constatar 0 estresse: " 0 rato não precisa da vitamina $C$ igual a gente. 0 rato consegue sintetizar vitamina C. M elhor! N essas vias de transformação para cortisol, que é um hormônio do córtex da supra-renal, ou para adrenalina ou noradrenalina, que é um hormônio também produzido no órtex da adrenal, os ratos usam 0 ácido ascórbico omo doador de elétrons. 0 u seja, se 0 bicho estiver estressado, 0 que aconteœe com a quantidade de ácido ascórbio? V Vi ser zero! E le usa o ácido ascórbico para fazer o hormônio. Q uanto mais estressado, mais hormônio e, por sua vez, menos áaido ascórbio" .

Explicou que a atividade experimental consistia na avaliação e constatação do estresse pelo conteúdo de ácido ascórbico da glândula supra-renal do rato e que existiam outras maneiras de avaliar o estresse. Uma delas seria colocar o rato durante cinqüenta minutos em natação inescapável; outra seria colocá-lo numa condição altamente estressora, como a queda de temperatura. Nessa condição, o hipotálamo é acionado e vai mexer muito com a glândula supra- 
renal. Essa seria a maneira utilizada, nessa aula prática, para avaliar e constatar o estresse no rato, por meio de um estudo comparativo da dosagem de ácido ascórbico de sua supra-renal. Assim, seria verificado quanto desse ácido haveria na glândula supra-renal do rato controle e quanto do mesmo ácido foi utilizado pelo rato mantido no congelador para produção do hormônio.

O formador descreveu aos alunos a técnica utilizada para o sacrifício dos animais e retirada da glândula (operações realizadas pelo técnico responsável do laboratório de ensino), bem como 0 método da dosagem, os materiais e as substâncias utilizadas. Os alunos acompanharam bem de perto todo o desenvolvimento da atividade prática e auxiliaram o professor nos cálculos envolvidos na dosagem do ácido ascórbico. No final, o formador escreveu na lousa os cálculos dessa dosagem presente nas glândulas supra-renais dos dois animais e explicou os passos realizados para a obtenção dos resultados, mostrando que a presença de ácido ascórbico, no rato que foi submetido à baixa temperatura, foi significantemente menor do que no rato controle.

O formador finalizou a aula reforçando suas explicações sobre os principais conceitos envolvidos no tema estresse, relacionando com a queda na taxa de ácido ascórbico da supra-renal do rato submetido ao frio, comparada à do outro rato. E assim, a aula chegou ao seu final. Muitos alunos se reuniram em volta do formador para tirar cópia da aula, outros para tirar dúvidas.

\section{Análise da aula}

A análise da aula evidencia aspectos essenciais para a compreensão do modo como 0 professor promoveu a elaboração conceitual sobre estresse. 0 primeiro refere-se ao relacionamento explícito entre os conceitos que compõem o tema central da aula. Ao estabelecer essas relações, o formador fez uma sistematização hierárquica dos conceitos. Associado a isso, fez uma síntese das principais idéias trabalhadas, as quais iam sempre em direção ao conceito central da aula. Isso evidencia que o formador não se satisfaz apenas com a definição dos conceitos, ao articulá-los a outras idéias para reforçar suas explicações e, também, para que os alunos entendam melhor os conceitos relacionados ao estresse.

D e acordo com Vygotsky (1993, p. 215), para que um conceito possa ser submetido à consciência e ao seu uso deliberado, ele necessita fazer parte de um sistema, pois, se consciência significa generalização, esta, por sua vez, significa a formação de um conceito superior, 0 qual implica a existência de uma série de conceitos subordinados. Esse conceito superior pressupõe, ao mesmo tempo, a sistematização hierárquica dos conceitos inferiores a ele subordinados, com os quais se relaciona por meio de um determinado sistema de relações. Assim, "a generalização do conceito leva à localização do mencionado conceito em um determinado sistema de relações de generalidade, relações que constituem as conexões mais naturais e mais importantes entre eles. Por conseguinte, a generalização significa, ao mesmo tempo, a tomada de consciência e a sistematização dos conceitos".

0 segundo aspecto, com base nas idéias desse teórico, diz respeito ao confronto entre o conceito científico estresse e uma concepção cotidiana do mesmo. Com esse confronto, 0 formador tenta dar concretude às suas explicações, e articular os conceitos científicos que 
compõem o tema central da aula a conhecimentos relacionados com situações próprias das vivências dos alunos. Ao proceder dessa maneira, o professor mostra como os conceitos científicos justificam ocorrências no cotidiano de vida, promovendo, numa perspectiva bakhtiniana, lingüística, uma articulação, um confronto entre significados expressos por diferentes vozes, tanto representativas do conhecimento científico quanto do senso comum, a do cotidiano, presentes em textos científicos introduzidos na aula e na fala cotidiana dos alunos. Esses relacionamentos e articulações conceituais, que o professor formador estabelece na sala de aula, configuram uma prática docente distinta da usual pois, nesta, os conteúdos são transmitidos de maneira fragmentada e linear, com definições prontas e acabadas, não permitindo ao aluno compreender a dimensão humana e sócio-histórica do conhecimento científico.

O utros aspectos importantes estão relacionados à preocupação do formador em justificar a prática assumida, ao explicitar, para os alunos, um contexto no qual o conteúdo por ele ensinado poderia ser significativo do ponto de vista experimental, da construção humana da ciência. Isso é evidenciado quando ele diz: "Para que serve isso? Para a gente entender estresse, ver as coisas sobre 0 estresse, mecanismos adaptativos, e, para quem da biologia for para a área de pesquisa, é uma técnica de rotina para vooê determinar se há um estresse no bicho.... V oô vai ex plicar o estresse!"

Tal preocupação tem sua importância na medida em que a explicitação do contexto em que os conteúdos podem ser significativos tem merecido pouca ou nenhuma consideração por parte de muitos professores universitários/ formadores das disciplinas científicas específicas. Isso porque seus ensinos, geralmente, têm se limitado a um tratamento instrumental dos conteúdos, sem que os alunos percebam qualquer tipo de aplicação social do conhecimento científico, nem mesmo para os cientistas.

\section{Mediação docente e elaborações discentes}

No desenvolvimento dos conteúdos nas aulas, a mediação pedagógica do professor formador, particularmente evidenciada na promoção de elaboração conceitual por parte dos alunos, é por estes analisada da seguinte maneira:

"A disciplina de Fisiologia édifícil. E u acho que a forma como ele [o professor] passa para a gente não é difícil, porque esses assuntos que a gente está aprendendo, que às vezes eu acho simples, têm muita gente que fala: ah! É um horror, super complicado! E u acho que é a maneira como ele ex plica que acaba facilitando. E le deix a de uma forma mais clara, fala como funciona, relacionando muito com coisas do dia-a-dia" (aluno 1).

"O professor faz muitas ligações de uma coisa com outra pra gente entender!! V ocê percebe que ele sabe muito e sabe passar pra gente, que isso é o mais importante, porque não adianta saber e não saber passar para você! E u já tive professor assim aqui, que sabia muito, e no ano passado, nós tivemos que tirá-lo! E le faz muita ligação entre uma coisa e outra. E le não fala, por ex emplo, de respiração e pronto! E le fala de um outro assunto, mas que está ligado com respiração. E le faz essas ligacõos" (aluno 2). 
Esses depoimentos remetem às seguintes questões: o profundo conhecimento dos conteúdos científicos disciplinares é competência de ensino suficiente para a promoção de aprendizagem nos alunos? Tal competência assegura condições adequadas para a promoção da elaboração conceitual nos alunos ou exige ser também pautada em estratégias lingüísticas mediadoras da compreensão dos alunos? A mediação na sala de aula exige que o professor formador tenha domínio do conhecimento dos seus conteúdos de ensino, isto é, saiba integrar o conhecimento acadêmico dos conteúdos biológicos ao conhecimento pedagógico implícito em tais conteúdos, tornando-os pedagogicamente acessíveis para serem compreendidos e apropriados pelos alunos. Tal pensamento parece ir ao encontro de idéias de Fraser e Tobin (apud MALDANER, 2000) que, ao estudarem práticas eficientes de ensino, observaram que estas, além das crenças dos professores sobre ensino e aprendizagem, envolvem profundos conhecimentos pedagógicos e de conteúdos específicos. Isso se confirma nas palavras dos alunos abaixo transcritas.

"A s oisas interessantes que ele traz são as ex plicaõoes dele! E le tem um conhecimento muito minucioso da matéria e isso faz com que você entenda. É impossivel você não prestar atenção e não entender! Tem dúvida? V ooê pergunta, você questiona, mas é impossivel você não entender! N ão tem œomo a pessoa não entender, sair da sala com dúvida! T êm vezes que eu vou para casa e eu leio 0 livro de Fisiologia, trago algumas dúvidas e ele esclarece. E le faz uns resumos, por ex emplo, a gente vai estar vendo hipófise. E le desenha a adenohipófise e faz uns caminhos mais curtos. E le desenha na lousa e, com esses desenhos, você consegue assimilar melhor a matéria" (aluno 3).

Essas falas revelam que as estratégias utilizadas pelo formador, para desenvolver os seus conteúdos de ensino - como a utilização de ilustrações/ imagens acompanhadas de suas explicações - , destacam-se como um dos pontos fortes da sua mediação pedagógica, demonstrando que ele procura utilizar diferentes modos de representar e formular os conhecimentos científicos de sua disciplina. Isso parece estar de acordo com o que dizem Cerri et al. (2000) sobre a importância da utilização de ilustrações/ imagens para tornar os conteúdos científicos acessíveis e apropriáveis pelos alunos.

"E le sempre chama a atencão de todo mundo que está na sala. E le ex põe, ao mesmo tempo ele já coloca uma transparência: olha, aqui acontece isso! Já traz uma imagem! Se ele está mostrando 0 órgão: é essa região, é essa célula, está fazendo tal coisa! A cho que é importante a gente estar relacionando. E star com uma coisa mais clara, uma imagem, você acaba relacionando melhor. E le usa esquemas que ele mesmo faz, às vezes, na lousa; eu acho legal, também, porque ajudam" (aluno 1).

Além dessas estratégias, outras utilizadas pelo formador dizem respeito ao emprego de textos científicos sobre temas atuais, assim como de situações do cotidiano, próximas às experiências e vivências dos alunos.

"0 professor faz vooê entender bastante ao trazer o dia-a-dia. E sse é o X !! 0 recurso importante do professor é essa dinâmica, trazer o que está no dia-a-dia, os ex emplos! $\mathrm{V}$ oôe estar informado no cotidiano. E le traz para o seu assunto de aula um ex emplo prático que o aluno esteja familiarizado e joga a matéria nele, a coisa tende a ser mais fácil!" (aluno 4). 
"Todas as aulas, ele traz material novo, sempre está trazendo ooisa nova: olha! Saiu uma droga relacionada à fisiologia! E le traz artigo de revista, de publicacão. E le sempre está traz endo coisas novas e colocando na matéria dele. Isso prende totalmente a atenção. E stimula voố, muitas vezes, a estudar mais fisiologia. D e recursos da aula dele, ele usa tudo que é possível" (aluno 5).

Esses depoimentos a respeito das estratégias de ensino do professor formador evidenciam que os alunos conseguem estabelecer relações entre a pretensão do formador para que eles desenvolvam uma compreensão dos conceitos científicos, isto é, uma elaboração conceitual deliberada, e os seus modos de ensinar. Nesse sentido, a pretensão do professor formador parece se confirmar nos depoimentos dos alunos, como os apresentados a seguir, sobre suas aprendizagens ou conviç̧ões a respeito de suas aprendizagens, as quais em nenhum momento foram relacionadas ao sucesso nas provas/ avaliações.

\begin{abstract}
"Q uando voôe sai e, por ex emplo, uma pessoa te faz uma pergunta, ou voôe ouve conversas do assunto ou ouve na televisão e, quando vooê menos espera, vooê está acompanhando a idéia ou quando voồ onsegue responder uma pergunta. V ooê consegue e vooê mesmo se surpreende: ah! É verdade, acontece isso, isso e isso!! E ntão, ele [0 professor] está conseguindo passar, porque voố aprende! V ooê vê que vooê aprendeu, voô̂ vai conversar sobre 0 assunto e 0 assunto começa a rolar" (aluno 4).
\end{abstract}

"N as situa ọes do dia-a-dia. E u lembro que meu pai estava com inchaco na próstata e ele teve que fazer um ex ame, deu um resultado alto. E ntão, já deu para eu perceber a gravidade da coisa, por ter aprendido na Fisiologia. E em outras disciplinas, eu também já usei o conhecimento que aprendi com 0 professor" (aluno 6).

"E u estava conversando com uma amiga que faz Farmácia. E la tinha um trabalho para apresentar sobre um medicamento e o professor ex plicou sobre os receptores. E la perguntou: vooê sabe sobre receptor? E u falei: até sei alguma ooisa! A í a gente comecou a conversar. Tudo que ela tinha usado como ex emplo eu comecei até a acrescentar coisas. E u falei: mas, tem receptor de ocitocina, tem receptor de não sei 0 quê!! E la falou: olha, a sua Fisiologia é melhor que a minha" (aluno 7).

Tais afirmações evidenciam que os alunos transferem os conhecimentos adquiridos na sala de aula por meio do professor formador/ mediador para outros contextos e para situações novas, bem como utilizam os conhecimentos aprendidos nessa disciplina para enfrentar problemas práticos. São indícios de que o professor formador/ mediador, ao procurar articular conhecimentos científicos e conhecimentos cotidianos, ao trazer outras vozes, como as dos textos científicos com temas atuais, em suas estratégias pedagógicas, promove uma construção de significados com sentido social em seus alunos.

Com base no que foi exposto, podemos apontar que a mediação pedagógica do formador inclui aspectos que promovem uma aprendizagem desejável em termos de elaboração de conhecimentos científicos por parte de seus alunos. Como decorrência, eles o vêem como um formador, no qual podem se referenciar para suas atuais e/ ou futuras ações docentes:

"A maténia de Fisiologia já me ajudou muito, tanto no meu lado profissional, que eu trabalho fora, quanto também para dar aula, porque, às vezes, alguma informação interessante 
que ele deix ou para a gente, esses paralelos que ele faz, essas pontes que ele faz, a gente consegue passar para os alunos e fazer com que os alunos prestem atenção. Você toma como base o professor! E ntão, no meio da aula, você pára, conversa, vocêtraz os alunos, pux a mais algumas outras coisas, que, às vezes, até fogem da matéria que está sendo dada, mas não da Biologia em si "(aluno 3).

"E u acho que é a metodologia dele que vale para mim. 0 jeito que ele ensina aquela matéria! Inclusive, eu estou usando agora, porque é uma coisa que está prendendo a atenção dos alunos, coisa que eu nunca tinha conseguido! E eu vou lembrando da metodologia, da didática do professor, que eu acho que funcionava muito om a gente e eu vou ex pondo isso para os meus alunos" (aluno 10).

Esses depoimentos, somados aos demais transcritos, evidenciam que a mediação pedagógica do formador pode superar a separação entre formação científica e pedagógica e, também, entre ensinar/ aprender conteúdos científicos e ensinar/ aprender a ser professor de Biologia. Tal constatação reveste-se de fundamental importância ao levarmos em conta o contexto usual da formação docente inicial em Biologia. Nesse contexto, a maioria dos professores formadores não tem se comprometido com a formação docente, ainda que atuando nas licenciaturas, nas quais, de qualquer modo, estão formando ou ajudando a formar profissionais para 0 exercício da docência nessa área. Concebem que, para ensinar e preparar os licenciandos para atuarem nas escolas de ensino fundamental e médio, basta-lhes o profundo conhecimento dos conteúdos científicos de suas disciplinas. Seus modos de ensinar geralmente estão voltados somente para a transmissão de tais conteúdos, desconsiderando as questões pedagógicas que os acompanham. Nessa atuação, acabam separando a formação em conteúdos da formação docente específica, atribuindo esta a outros formadores, os(as) que ministram disciplinas pedagógicas. Essa concepção de formação docente, não deliberada, usualmente assumida por aqueles formadores, promove, nos futuros professores, uma visão simplista de docência: a de que para ensinar basta ao professor conhecer o conteúdo, associando a ele algumas técnicas pedagógicas, para transmiti-lo aos alunos, que devem reproduzi-lo. Em outros termos, tal concepção promove nos licenciandos, numa perspectiva de "formação ambiental", o desenvolvimento de um conjunto de crenças e teorias sobre a docência que também constituem posturas profissionais de professores, e podem se tornar predominantes na ação docente, porque adquiridas de maneira reiterada e não deliberada (CARVALHO e G IL-PÉREZ, 1993).

\section{Considerações finais}

Os resultados desta pesquisa evidenciam que a mediação pedagógica do formador investigado promove a elaboração conceitual em seus alunos, constituindo-se, ainda, como referência para futuras atuações no exercício da docência. Isso porque o formador tem uma preocupação em sistematizar os conceitos de sua disciplina, articulando-os com conhecimentos construídos cotidianamente pelos alunos, utilizando-se de recursos pedagógicos variados. Associado a isso, concretiza a perspectiva dialógica em sala de aula, ao trazer textos com temas atuais, situações do cotidiano, que expressam outras vozes do conhecimento científico e do conhecimento cotidiano, as quais se articulam e confrontam-se no processo de elaboração 
conceitual pelos alunos. Isso vem ao encontro do que propõe Mortimer (1998, p. 117), inspirado nas idéias de Bakhtin, para as aulas de Ciências:

implementar uma perspectiva dialógica em sala de aula não significa apenas dar "voz" ao aluno e à aluna. Significa, também, contemplar vozes da linguagem cotidiana e dos contextos sociais e tecnológicos onde a ciência se materializa, na construção do discurso científico escolar de sala de aula. Uma aula expositiva ou um texto podem ser profundamente dialógicos, desde que explicitamente contemplem essas outras vozes que não apenas as da linguagem científica. Essa perspectiva também se aplica à atividade experimental, que pode, dessa maneira, ser caracterizada como um diálogo entre teoria e prática.

Nessa perspectiva, as aulas expositivas do professor formador investigado têm um significado diferente do usual a elas atribuído: aulas improdutivas porque privilegiam a transmissão de uma elevada quantidade de conteúdos, não possibilitam a elaboração/ reelaboração de outros/ novos conhecimentos; não dão voz aos alunos, ignorando suas idéias e dúvidas; impedem diálogos e garantem o monopólio e a autoridade da voz docente. Com base no pensamento de Machado (1999, p. 182), podemos afirmar que as aulas do referido professor formador são muito mais que um tempo durante o qual ele se dedica a ensinar biologia/ fisiologia e os alunos a aprenderem alguns conceitos e desenvolverem habilidades. Elas são um espaço de elaborações de conhecimentos e "de visões de mundo e, nesse sentido, são espaço de constituição de sujeitos que assumem vozes, perspectivas, posições no mundo. Sujeitos que aprendem várias formas de ver, de conceber e de falar do mundo".

D esse modo, a análise da mediação pedagógica do professor formador investigado evidencia, ainda, o papel mediador da linguagem nos processos de apropriação e de elaboração de conhecimentos na sala de aula, pois, por meio dela, ele procura maximizar as possibilidades do ensino para a construção de significados, pelos alunos, aos conceitos por ele abordados.

Considerando, com Vygotsky (1993, 2000a), que a imitação é a principal forma em que se realiza a influência da aprendizagem sobre o desenvolvimento, e de que 0 ensino na escola se baseia fundamentalmente na linguagem, o professor formador oferece aos seus alunos uma referência de atuação docente.

Nesses termos, esta investigação sobre a mediação pedagógica de um professor universitário tem importância para a formação docente inicial, pois, é sabido que professores iniciantes, especialmente os do ensino médio, se deparam com problemas que se referem a aspectos didáticos, em oposição a pessoais ou organizacionais e, assim, na busca de soluções para esses problemas, eles recorrem à imitação dos modos de atuação de seus formadores (MARCELO, 1999; IMBERNÓN, 2001). Por isso, conforme expressa Imbernón (2001, p. 63), "o modelo aplicado (planejamento, estratégias, recursos, hábitos e atitudes) pelos formadores atua também como uma espécie de 'curríaulo oculto' da metodologia". Portanto, contribuições desta investigação se situam no fato de termos adentrado a sala de aula de um professor universitário de disciplina científica específica e de desvelarmos a sua mediação pedagógica, a qual evidencia possibilidades de melhoria na formação docente inicial, reafirmando a importância do papel mediador dos formadores dessas disciplinas na constituição docente de futuros professores. 


\section{Referências}

BAKHTIN, M. Marxismo e filosofia da linguagem. São Paulo: Hucitec, 1997. Q Q uestões de literatura e de estética. 4. ed. São Paulo: Hucitec, 1998.

CARVALHO, A. M. P.; GIL-PÉREZ, D. Formação de professores de ciências: tendências e inovações. São Paulo: Cortez, 1993.

. O saber e o saber fazer dos professore. In: CASTRO, A. D.; CARVALHO, A. M. P. (orgs.). Ensinar a ensinar. São Paulo: Pioneira, 2001.

CERRI, Y. N. S.; NADALINI, M. F. C.; SILVA, L. H. A.; PERUZZI, H. B. U. Modelo de Ensino: célula. In: ARAG ÃO, R. M.R.; SCHNETZLER, R. P.; CERRI, Y. N. S (orgs.). Modelos de ensino: corpo humano, célula, reações de combustão. Piracicaba: Capes/ Unimep, 2000.

CICILLINI, G. A. A produção do conhecimento biológico no contexto da cultura escolar do ensino médio: a teoria da evolução como exemplo. Campinas. 1997. Tese (D outorado) - Faculdade de Educação, Unicamp.

FONTANA, R. A. C. Mediação pedagógica na sala de aula. Campinas: Autores Associados, 1996.

GÓES, M. C. R. As relações intersubjetivas na construção de conhecimentos. In: GÓES, M. C. R.; SMO LKA, A. L. B. (orgs.). A significação nos espaços educacionais: interação social e subjetivação. Campinas: Papirus, 1997.

- A abordagem microgenética na matriz histórico-cultural: uma perspectiva para 0 estudo da constituição da subjetividade. Cadernos CEDES. Campinas, n. 50, p. 21-29, 2000.

IMBERNÓ N, F. Formação docente e profissional: formar-se para a mudança e a incerteza. São Paulo: Cortez, 2001.

MACHAD O, A. H. Aula de química: discurso e conhecimento. Ijuí: Unijuí, 1999.

MALDANER, O. A. A formação inicial e continuada de professores de química. Ijuí: UNIJUÍ, 2000.

MARCELO, C. G. Formação de Professores - para uma mudança educativa. Barcelona: Porto Editora, 1999. 
MORTIMER, E. F. Sobre chamas e cristais: a linguagem cotidiana, a linguagem científica e o ensino de Ciências. In: CHASSOT, A. O.; OLIVEIRA, R. J. (orgs.). Ciência, ética e cultura na educação. São Leopoldo: Unisinos, 1998.

SCHNETZLER, R. P. 0 professor de ciências: problemas e tendências de sua formação. In: SCHNETZLER, R. P.; ARAGÃO, R. M. R. (orgs.). Ensino de Ciências: fundamentos e abordagens. Piracicaba: Capes/ Unimep, 2000.

SHULMAN, L. Those who understand: the knowledge growths in teaching. E ducational Research, v. 15, n. 2, p. 4-14, 1986.

SMO LKA, A. L. B. E sboço de uma perspectiva teórico-metodológica no estudo de processos de construção de conhecimento. In: GÓES, M. C. R.; SMO LKA, A. L. B. (orgs.). A significação nos espaços educacionais: interação social e subjetivação. Campinas: Papirus, 1997.

MO LKA, A. L. B.; GÓES, M. C. R. (orgs.). A linguagem e o outro no espaço escolar: Vygotsky e a construção do conhecimento. 9. ed. Campinas: Papirus, 2003.

VYG OTSKY, L. S. A formação social da mente. São Paulo: Martins Fontes, 2000a. p. 21-44, 2000b.

. Psicologia concreta do homem. Educação \& Sociedade. Campinas: Cedes, n. 71, . Pensamento e linguagem. 2. ed. São Paulo: Martins fontes, 2000c.

. Obras escogidas II. Madrid: Centro de Publicaciones del MEC y Visor Distribuiciones, 1993. 